\title{
New taxa and a new combination in Triodia (Poaceae)
}

\author{
S.W.L. Jacobs
}

\begin{abstract}
Jacobs, S.W.L. (National Herbarium of New South Wales, Royal Botanic Gardens, Sydney, N.S.W., Australia, 2000) 1992. New taxa and a new combination in Triodia (Poaceae). Telopea 4(4): 653-659. The Triodia irritans complex is reassessed. T. irritans var. laxispicata is treated as a synonym of $T$. scariosa; a new combination is made for $T$. compacta; and $T$. scariosa subsp. bunicola, $T$. scariosa subsp. yelarbonensis, $T$. truncata, $T$. tomentosa and $T$. radonensis are described as new. All but the last species belong to the $T$. irritans group.
\end{abstract}

\section{Introduction}

Burbidge (1953) treated the Triodia irritans complex by recognising $T$. irritans, $T$. scariosa, $T$. lanata and three varieties within $T$. irritans: var. irritans, var. compacta and var. laxispicata. Three informal forms (designated A, B and C) were described in $T$. irritans var. laxispicata. Unfortunately, the type of $T$. irritans var. laxispicata is conspecific with $T$. scariosa. Rectifying this problem for the 'Flora of New South Wales' presents an opportunity for a reassessment of the $T$. irritans complex and the description of some new taxa.

\section{The $T$. irritans complex}

Two of the forms of $T$. irritans var. laxispicata (' $\mathrm{B}$ ' and ' $\mathrm{C}$ ') are geographically isolated and show little character overlap, can be recognised in the field, and are as distinct as varieties recognised in T. mitchellii and T. pungens (Burbidge 1953, 1960). T. irritans var. compacta is distinct from both $T$. scariosa and T. irritans and, if anything, is more closely related to the former than to the latter. $T$. irritans var. compacta is here recognised at the species level as T. compacta. T. compacta differs from both in the shorter rhachilla segments and denser-flowered spikelets with almost twice the number of florets per spikelet. Similar relative glume lengths and emarginate lemmas are shared by $T$. compacta and $T$. scariosa. To reflect the taxonomic situation and to simplify communication by changing the present subspecific classification from two formal levels and one informal level to a system of two formal levels, I propose to recognise $T$. irritans var. compacta at the species level, treat $T$. irritans var. laxispicata form ' $A$ ' as a synonym of $T$. scariosa and to recognise forms ' $B$ ' and ' $C$ ' of $T$. irritans var. laxispicata as subspecies of T. scariosa.

Triodia compacta (N.T. Burbidge) S.W.L. Jacobs, comb. et stat. nov.

BASIONYM: Triodia irritans var. compacta N.T. Burbidge (1953: 169).

LectotyPe (here designated): SOUth Australia: Elliston Beach, Eyre Peninsula, J.H. Willis, 26 Aug 1947 (CANB); isolecto MEL. 
Burbidge designated both specimens as the 'holotype'; I have selected the specimen at CANB where she worked as lectotype.

Triodia scariosa N.T. Burbidge (1953: 173).

Holotype: Western Australia: Pioneer Rock, N of Lake Cowan, N.T. Burbidge 2675 (CANB).

\section{Triodia scariosa subsp. scariosa}

Triodia irritans var. laxispicata N.T. Burbidge (1953: 171), syn. nov.

LECTOTYPE (here designated): NEW SOUTH WALES: South Far Western Plains: Tooleybuc, J. Vickery, 14 Oct 1949 (CANB); isolecto NSW.

Burbidge designated both specimens as the 'holotype'; I have selected the specimen at CANB, where she worked, as lectotype.

T. irritans var. laxispicata N.T. Burbidge 'forma A' belongs here.

Triodia scariosa subsp. bunicola S.W.L. Jacobs, subsp. nov.

Subsp. scariosae affinis, sed lemmatibus glumisque longioribus, spiculis longioribus latioribusque, differt.

Holotype: South Australia: Flinders Ranges N of Hawker, S. Jacobs, 19 Aug 1966 (SYD).

Hummock-forming perennial. Leaf sheath, orifice and blade glabrous, blade pungentpointed. Inflorescence paniculate, contracted, $15-30 \mathrm{~cm}$ long. Spikelets $12-20 \mathrm{~mm}$ long, 7-10 mm wide when lemmas divergent. Glumes $8-12 \mathrm{~mm}$ long. Lowest lemma 8-10 mm long; lemma apex emarginate, mucro usually absent. Palea shorter than to subequal to its subtending lemma.

Based more or less on T. irritans var. laxispicata N.T. Burbidge 'forma B' but with a 'type' different to that indicated in the informal publication of that form and excluding those of the originally cited specimens not from the southern Flinders Range.

From the Greek bounos (Latinised to bunus), hill or mound, and the Latin -cola, dweller, i.e. hill-dweller.

НАвІтAт: On hill slopes and once-wooded areas now often cleared for grazing.

Distribution: On slopes of the Flinders Ranges and adjacent areas, South Australia.

Selfeted specimens: South Australia: Port Germein Pass, Blake 16856, 29 Aug 1946 (NSW, BRI); between 'Yednalue' and Flinders Ranges, Jacobs, 22 Aug 1966 (SYD); $N$ of Hawker on main road, Jacobs, 20 May 1966 (SYD); Flinders Range, Koch, Oct 1901 (NSW).

Triodia scariosa subsp. yelarbonensis S.W.L. Jacobs, subsp. nov.

Subsp. scariosae affinis, sed spiculis angustioribus, lemmatibus villosioribus brevioribus latioribusque, differt.

Holotype: New SOUTH WALES: North Western Slopes: on New South Wales-Queensland border, P. Vickery, c. 1933 (NSW). 
Hummock-forming perennial. Leaf sheath, orifice and blade glabrous, blade pungentpointed. Inflorescence paniculate, contracted, $10-25 \mathrm{~cm}$ long. Spikelets $7-18 \mathrm{~mm}$ long, 3-5 $\mathrm{mm}$ wide when lemmas divergent. Glumes $5.5-7 \mathrm{~mm}$ long, often lightly scabrous. Lowest lemma 4.5-6 mm long, comparatively shorter and with longer hairs (to $1.5 \mathrm{~mm}$ long) than in the other subspecies; apex emarginate, usually with a short mucro.

Based on T. irritans var. laxispicata N.T. Burbidge 'forma C'.

Named after a small town, Yelarbon, near the centre of its distribution.

Habitat: Poor alluvial soils along the Dumaresq River and some of its northern tributaries.

DistRIBUTION: Both sides of the Queensland-New South Wales border from about Inglewood to Goondiwindi.

SPeCrmens eXamineD: QueEnsLand: Goondiwindi, Shirley 4525/19, Nov 1919 (NSW); InglewoodTexas road, $4 \mathrm{~km}$ from Inglewood, Simon 2864 A, Pedley $\mathcal{E}$ McDonald, 3 Sept 1975 (BRI, NSW); c. $2 \mathrm{~km} \mathrm{~S}$ of Yelarbon, Keetah Bridge-Yetman road, Wilson 1367, Oct 1975 (NSW).

Triodia truncata S.W.L. Jacobs, sp. nov.

T. scariosae affinis sed apice lemmatis lacerato truncatoque, costa lemmatis excurrente, lemmatibus 3-nervibus brevioribus latioribusque, differt.

Holotype: South Australia: 56 miles [90 km] WNW of Emu, N. Forde 537, 14 Sept 1956 (NSW); iso CANB.

Hummock-forming perennial. Leaf sheaths glabrous, smooth, 2-3 mm wide, the margins with a few hairs to $0.5 \mathrm{~mm}$ long near the top; orifice with a few hairs to $0.5 \mathrm{~mm}$ long that become woolly with age, ligule a ciliate rim; blade to c. $12 \mathrm{~cm}$ long, permanently folded, pungent-pointed. Inflorescence paniculate, contracted, 10-15 cm long. Spikelets 4-6-flowered, 10-12 $\mathrm{mm}$ long. Glumes equal, c. $7 \mathrm{~mm}$ long, broadly lanceolate, acute, scabrid along the midrib. Lowest lemma c. $7 \mathrm{~mm}$ long, $3 \mathrm{~mm}$ wide, 3 -nerved, hairy in the lower half with hairs to $2 \mathrm{~mm}$ long; apex raggedly truncate, very shortly ciliate, with the midnerve excurrent as a scabrid mucro $0.25-0.5 \mathrm{~mm}$ long. Palea c. $5 \mathrm{~mm}$ long, with a few tangled hairs to $1 \mathrm{~mm}$ long at the base; apex minutely 2-lobed. Stamens 3, c. $3 \mathrm{~mm}$ long. Caryopsis not seen. Fig. 1.

HabitAт: Reportedly in interdune areas with Acacia aneura.

DistRibution: Known only from the type.

Named for the characteristically truncate lemmas.

Triodia tomentosa S.W.L. Jacobs, sp. nov.

T. lanatae affinis sed glumis longioribus glabrisque, lemmatibus longioribus acutisque, differt.

Holotype: Western Australia: Great Northern Highway, $6 \mathrm{~km}$ SW of Paynes Find, $29^{\circ} 18^{\prime} \mathrm{S} 117^{\circ} 36^{\prime} \mathrm{E}$, M.G. Corrick 9324, 24 Oct 1984 (NSW); iso MEL.

Hummock-forming perennial to c. $40 \mathrm{~cm}$ diam. Sheaths $2-3 \mathrm{~mm}$ wide, woolly-hairy with hairs c. $1 \mathrm{~mm}$ long; the orifice with similar tangled hairs and these extending 

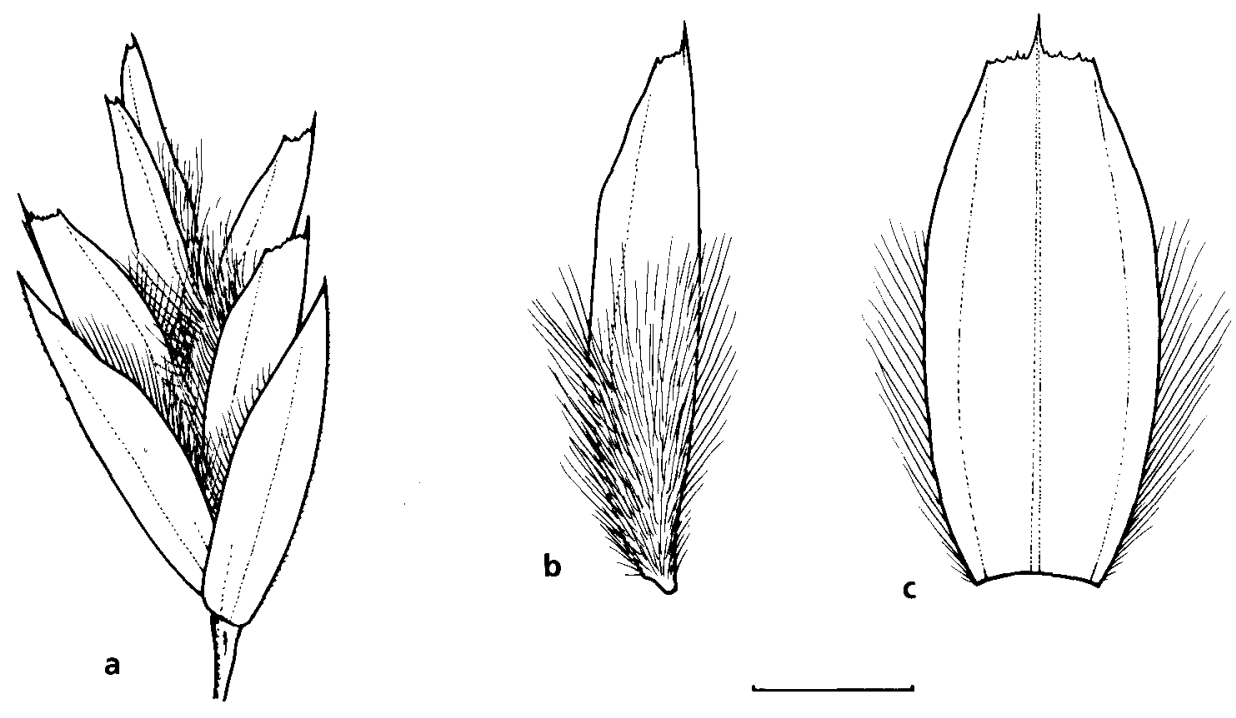

Fig. 1. Triodia truncata $\mathbf{a}$, whole spikelet; $\mathbf{b}$, lateral view of lemma; $\mathbf{c}$, adaxial view of lemma. Scale bar $=3 \mathrm{~mm}$ for $\mathrm{a},=2 \mathrm{~mm}$ for $\mathrm{b} \& \mathrm{c}$. Drawn from N. Forde 537 (NSW) by David Mackay.
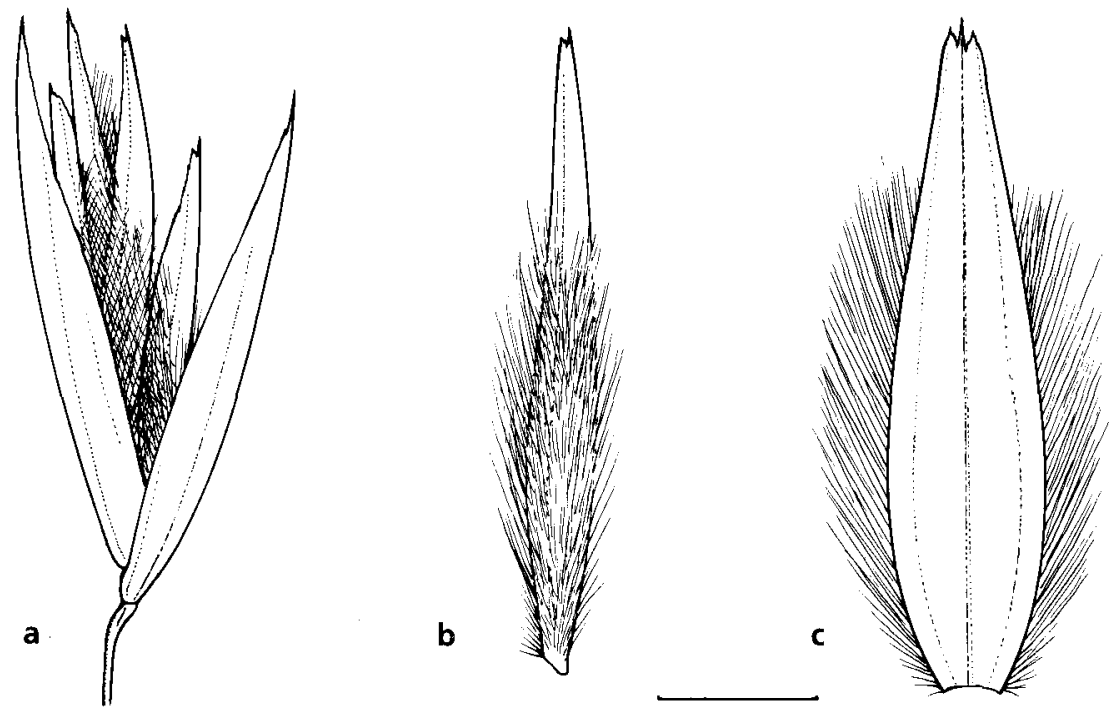

Fig. 2. Triodia tomentosa $\mathbf{a}$, whole spikelet; $\mathbf{b}$, lateral view of lemma; $\mathbf{c}$, adaxial view of lemma. Scale bar $=3 \mathrm{~mm}$ for $\mathrm{a},=2 \mathrm{~mm}$ for $\mathrm{b} \& \mathrm{c}$. Drawn from M.G. Corrick 9324 (NSW) by David Mackay. 
5-15 mm up the adaxial surface of the blade; blades to c. $10 \mathrm{~cm}$ long, permanently folded, pungent-pointed, glabrous except near the orifice. Inflorescence paniculate, contracted, 10-15 cm long. Spikelets 12-14 mm long, 4-5-flowered. Glumes equal, lanceolate, scarious, acute to aristate, 11-12 mm long, glabrous. Lowest lemma 3-nerved, 9-10 mm long, with hairs c. $2 \mathrm{~mm}$ long over the lower $60 \%$; the apex acute, emarginate, with the midnerve excurrent as a mucro $0.25-0.5 \mathrm{~mm}$ long. Palea acute, entire, c. $90 \%$ the length of the lemma, with scattered hairs c. $1 \mathrm{~mm}$ long at the base. Stamens 3, c. $4 \mathrm{~mm}$ long. Mature caryopsis not seen, immature caryopses typically chloridoid. Fig. 2.

HaBitat: Reportedly from an open woodland of Melaletica and Acacia.

DisTRiBUTiON: Only known from the type.

Named from the tomentose hairs of the sheath, orifice and lower blade.

\section{Key to the $T$. irritans group}

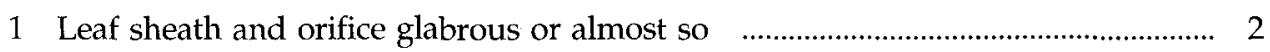

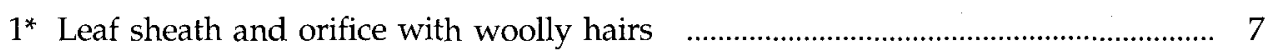

2 Lemma apex raggedly truncate, the midnerve excurrent as a mucro T. truncata

$2^{*}$ Lemma apex emarginate, obtuse or acute; if the midnerve excurrent then between lobes

3 Midnerve excurrent as a short awn between and longer than the stiff lobes; glumes subequal to the spikelet

T. irritans

3* Lemma apex emarginate, sometimes with a mucro shorter than the lobes; glumes usually shorter than the spikelet

4 Spikelets 8-12-flowered; lemmas closely distichous, lower rhachilla segments usually $<1 \mathrm{~mm}$ long

T. compacta

$4^{*}$ Spikelets mostly less than 8-flowered; lemmas loosely distichous, lower rhachilla segments usually $>1 \mathrm{~mm}$ long ……................................ T. scariosa and subspp. 5

5 Mature spikelets with divergent lemmas usually $<5 \mathrm{~mm}$ wide; lowest lemma 4.5-6 mm long T. scariosa subsp. yelarbonensis

$5^{*}$ Mature spikelets with divergent lemmas usually $>5 \mathrm{~mm}$ wide; lowest lemma $6 \mathrm{~mm}$ long or more

6 Glumes 5.5-9 mm long; lowest lemma 6-7 mm long .... T. scariosa subsp. scariosa

6* Glumes 8-12 mm long; lowest lemma 8-10 mm long ... T. scariosa subsp. bunicola

7 Glumes glabrous, 11-12 mm long; lowest lemma 9-10 $\mathrm{mm}$ long ..... T. tomentosa

$7^{*}$ Glumes hairy, $7-10 \mathrm{~mm}$ long; lowest lemma 6-8 mm long …..................... T. lanata 


\section{Triodia pungens group}

Triodia radonensis S.W.L. Jacobs, sp. nov.

T. microstachyae affinis sed glumis emarginatis vel 2-lobis, paleis alatis, lemmatibus tumidis induratisque, lobis lemmatis minutis membranaceisque, differt.

Holotype: Northern Territory: Radon Creek, Brockman Range, P.K. Latz 7676, 10 June 1978 (NSW); iso BRI, CANB, DNA, PERTH, K.

Viscid perennial forming loose hummocks to c. $5 \mathrm{~m}$ diam. Sheaths loose, to $15 \mathrm{~mm}$ wide; orifice with a few hairs to $0.5 \mathrm{~mm}$ long matted with resin; blades loosely folded, to c. $60 \mathrm{~cm}$ long, curved, not pungent-pointed. Inflorescence paniculate, open, 15-25 cm long. Spikelets 4-6-flowered, 6-8 mm long, c. $4 \mathrm{~mm}$ wide when the lemmas divergent, appearing open with rhachilla segments c. $1 \mathrm{~mm}$ long. Glumes subequal, membranous, c. $2 \mathrm{~mm}$ long, emarginate or 2-lobed, the lobes obtuse. Lowest lemma 2-3 mm long, 3-nerved, glabrous or the margins with very few scattered hairs, shiny, swollen and indurated; apex membranous, minutely 3-lobed. Palea subequal to the lemma, winged and the wings visible in the spikelet and ciliolate. Stamens $3,2 \mathrm{~mm}$ long. Mature caryopses not seen. Fig. 3.

HABITAT: Sandy levee banks.

DistRiBution: Known only from the type locality.

Named from the locality, Radon Creek in the Brockman Range, Northern Territory.
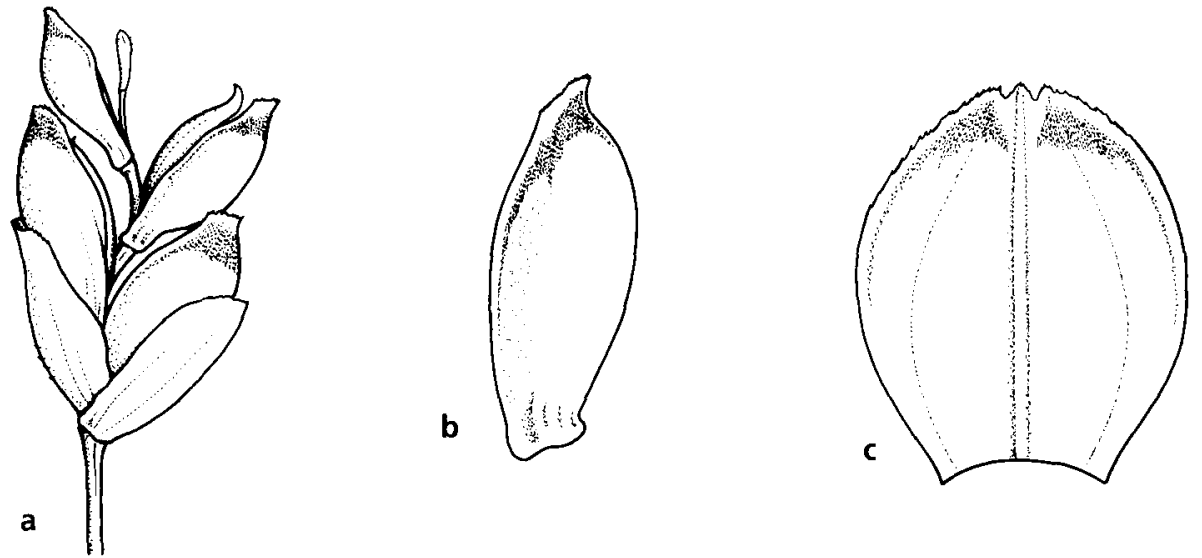

Fig. 3. Triodia radonensis $\mathbf{a}$, whole spikelet; $\mathbf{b}$, lateral view of lemma; $\mathbf{c}$, adaxial view of lemma. Scale bar $=3 \mathrm{~mm}$ for $\mathrm{a},=2 \mathrm{~mm}$ for $\mathrm{b} \& \mathrm{c}$. Drawn from P.K. Latz 7676 (NSW) by David Mackay

\section{Acknowledgments}

Many thanks to Karen Wilson for the Latin diagnoses, to Ken Hill for his helpful comments on the manuscript, and to David Mackay for his excellent art work. 


\section{References}

Burbidge, N.T. (1953) The genus Triodia R. Br. (Gramineae). Australian Journal of Botany 1: 121184.

Burbidge, N.T. (1960) Further notes on Triodia R. Br. (Gramineae) with description of five new species and one variety. Australian Journal of Botany 8: 381-394.

Manuscript received 15 July 1991

Manuscript accepted 17 October 1991 